University of South Florida

DIGITAL COMMONS

Digital Commons @ University of

@ UNIVERSITY OF SOUTH FLORIDA

South Florida

Academic Services Faculty and Staff

Publications

Tampa Library

2012

\title{
When the Pilot Is Over: Picking the Program and Making It Stick, Purchase on Demand at the University of South Florida
}

LeEtta M. Schmidt

University of South Florida, Imschmidt@usf.edu

Follow this and additional works at: https://digitalcommons.usf.edu/tlas_pub

Part of the Library and Information Science Commons

\section{Scholar Commons Citation}

Schmidt, LeEtta M., "When the Pilot Is Over: Picking the Program and Making It Stick, Purchase on Demand at the University of South Florida" (2012). Academic Services Faculty and Staff Publications. 177.

https://digitalcommons.usf.edu/tlas_pub/177

This Article is brought to you for free and open access by the Tampa Library at Digital Commons @ University of South Florida. It has been accepted for inclusion in Academic Services Faculty and Staff Publications by an authorized administrator of Digital Commons @ University of South Florida. For more information, please contact digitalcommons@usf.edu. 
When the Pilot is Over: picking the program and making it stick, Purchase on Demand at the University of South Florida

\begin{abstract}
:
In 2008 the Interlibrary Loan department of the University of South Florida, Tampa, began a Purchase on Demand program, using interlibrary loan requests to supplement Collection Development practices. After three years the program was analyzed for effectiveness and compared to other programs currently in operation. To achieve a complete evaluation, interlibrary loan patrons were surveyed on their awareness and use of the Purchase on Demand program. This article combines the analysis of USF's program with recommendations gained through administration and evaluation of Purchase on Demand.
\end{abstract}


When the Pilot is Over: picking the program and making it stick, Purchase on Demand at the University of South Florida

You've heard the spiels about how purchase on demand programs help interlibrary loan provide a valuable window on patron needs and add to the collection in an expedited and proactive manner. You know "that POD items circulated or were otherwise used more frequently than items acquired through traditional channels" (Tyler, 2011, p. 58) in programs that have been launched and analyzed all over the country. You believe that purchasing based on patron requests will use premium shelving space more effectively (Reighart, 2008), and that the "most timely and cost effective" interlibrary loan (ILL) service involves "expedited purchasing rather than borrowing" (Alder, 2007, p. 10). Now, you're ready to drink the Kool-Aid, but what is your first step?

Of course you'd never embark on a program before identifying the need in your specific environment, no matter what the success stories were telling you. As luck would have it, interlibrary loan's very purpose excludes it's use as a "substitute for good library collections" (ALA, 2008, para. 8) and, perhaps consequently, its request information has historically been used to supplement "routine collection development as an effective way to improve monographic purchasing decisions in a research library" (Ruppel, 2006, p. 76).

With the amount and span of literature dedicated to the success and value of purchase on demand programs covered by Nixon, Freeman, and Ward (2010) anyone would surmise that this practice has become part and parcel of interlibrary loan. Anyone would be wrong. Launching patron driven acquisition through interlibrary loan requires extensive planning, interdepartmental cooperation, and enough forethought to make the program stick, even when the project manager has moved on. What follows is a comparison of program types and implementations finished with an analysis of the University of South Florida, Tampa Library's purchase on demand program in action.

\section{Picking your poison}


One of the first things to consider is that not all purchase on demand (POD) programs are created equal, or meant for the same type of service or collection development. Each type of purchase on demand program currently in existence answers to specific library needs and works around specific library resources. For the purposes of categorization the models discussed will be rated on power and effect. Power relates to the range of autonomy given to the ILL staff, and effect relates to the value and efficacy of the books purchased for the collection. The model summaries are not intended to be exhaustive and can, of course, be reworked to fit whatever environment they must.

\section{Model 1. Purchase as a last resort: Maximum power, minimum effect}

Where library budgets are plummeting, interlibrary loan operations stick out like a sore expensive thumb. The business of interlibrary loan has never been a cheap one, even when ILL staff are trying their best to cut costs by maximizing on reciprocal agreements and consortial borrowing programs. When all the options for a free loan from a partner library have been exhausted, purchase can be a cheaper option than a pricey ILL service fee. "We could ask ourselves: do we buy the book for our user if it only costs $\$ 0.01$ with about a $\$ 3$ shipping" when borrowing from a library could be as much as $\$ 20$ (Reighart, 2008, p. 187).

Purchase as a last resort can be a seamless extension of interlibrary loan service, but will most likely end up acquiring titles the library may have no interest in keeping. The condition of the cheapest option may also be less than desired. If the library already has a process in place for handling gift books then the ILL purchase could be turned over to be evaluated and cataloged or discarded. If no process is in place for gift books, then creating one to take maximum advantage of all opportunities for materials acquired in this way would cost a large amount of staff time.

Purchasing in this way would often be no more permanent than paying an ILL fee for the loan of a book. However, this form of purchase on demand requires the most staff autonomy. Staff must be equipped with purchasing power of some sort and allowed to make decisions 
based on their individual expertise and analysis of the ILL request. Staff would need full access to ILL budget information to monitor spending and report on purchases.

\section{Model 2. Popular title acquisition: Maximum power, maximum effect}

One of the most prominent talking points for purchase on demand programs is the amount of circulation per title. Interlibrary loan requests become a prominent possibility for moving from just in case acquisition to just in time acquisition. Public libraries especially, may find that purchasing to fill patron demand is an efficient way of acquiring popular titles (Hulsey, 2003).

Popular title acquisition, like purchase as a last resort, requires that ILL staff have access to purchasing mechanisms and are allowed to make decisions based on their individual analysis of the request and the collection. In a way, it requires that ILL staff be able to, or already, wear many hats so they may serve as collection developer, acquisitions, and interlibrary loan. Just like any other collection developer, their choices will be flavored with their own opinions and prejudices.

\section{Model 3. Route to review: Minimum power, maximum effect}

Another method of circumventing the interlibrary loan borrowing process and purchasing items for the collection based on ILL requests is to refer requests to collection developers. This process takes the decision making out of ILL staff hands. However, because this method requires that the request information change hands a couple or more times, it can add inordinate amounts of time to the interlibrary request process. "Routine acquisition channels are not designed for speed" (Alder, 2007, p. 10), and yet a good purchase on demand program should integrate into existing processes of all involved departments, not overwrite them.

\section{Model 4. Selection Criteria: Moderate power, maximum effect}

The conundrum of maintaining the speed of ILL while providing additional service and benefit to the collection via a purchase on demand program has led many to selection based on preapproved criteria. Libraries whose focus is on the speed of fulfilling interlibrary loan requests 
may find that "sending a request to the relevant Subject Selector for consideration to purchase simply [takes] too long" (Alder, 2007, p. 10). Defining a selection criteria can satisfy the interests of all involved parties, especially in large libraries where the bulk of ILL processing is cared for by staff members who would not normally have purchasing or selecting powers. Including turnover time in these criteria can ensure that the program fits interlibrary loan service standards as well (Alder, 2007; Herrera, 2011).

\section{Beginning the program at USF}

USF wanted to avoid the time lost by sending interlibrary loan requests to Collection Developers. It was decided that the book would be purchased only if it could be obtained as fast or faster than an interlibrary loan unless purchasing was the only option, which sometimes ended up being the case with new and/or foreign publications. Books that could not be obtained fast enough were requested for loan. Collection development librarians would then use the request data after the fact, as they had been doing for years. After considering all the options, USF's purchase on demand program would be based on selection criteria.

In late Fall of 2007 Collection Development, Acquisitions, and the Head of Access Services knocked their brains together in an effort to develop selection criteria that would allow for the most beneficial purchasing while minimizing the potential for undesirable acquisition. The Purchase on Demand (POD) program was started in January 2008.

Selection Criteria:

- $\quad$ published within the last two years

- it is a monograph

- in the English language

- it is not a textbook

- it is not a manual

- non juvenile, fiction, or graphic novel

- $\quad$ non conference/symposia 
- non AV

- Costs less than $\$ 200$

Interlibrary loan should also request purchase of items requested by patrons that were previously owned and marked lost in the catalog. USF did not previously have in place any standardized replacement of lost items; the purchase on demand program would fill in the gap here, but the patrons would decide what lost materials were losses that should be rectified.

After a year of purchasing the guidelines were revised slightly to include items published within the last four years, instead of two. Non-English materials would be considered as well as symposia proceedings/conference papers if deemed worthy by the interlibrary loan manager. All purchases made on ILL requests would favor digital format first unless there were special instructions made at the time of request.

\section{Workflow}

Routing rules in ILLiad harvested every loan request put in by a patron that already had a date attached and moved them to a special queue that would alert staff to the action needed. ILL staff would still need to keep their eyes open for books fitting the criteria that did not have a patron provided date and therefore did not get caught by the routing rule. Identifying potential purchases was easy given the criteria, and required only that staff become accustomed to another if/then decision during their request processing.

When an item was identified for purchase an e-mail built into the system alerted acquisitions staff with full item information and routed the request to a status indicating it had been ordered. Acquisitions staff then did their own quick check to make sure the material requested fit the criteria. This came in handy when weeding out requests for textbooks that showed as such in systems like GOBI, but for which the item's OCLC record did not have this same information. Interlibrary loan staff would also assist acquisitions in finding retailers for especially hard to locate items. 
An item record would be created in the ILS during the order process and a note would be added to the acquisitions record that the item was purchased for the Interlibrary loan Purchase on Demand program. These notes would help cataloging staff rush the request once the book had arrived and made it possible to pull reports of all items purchased under the program.

\section{Statistics Analysis}

Though the program began slowly while ILL staff integrated the new workflow into daily processes, the amount of requests routed to purchase remained steady over the first three years of the program. Less than $10 \%$ of all borrowing requests were diverted for Purchase on

Demand. Similar to what was seen at University of Nebraska-Lincoln (Tyler, 2011) and what has been witnessed in many purchase programs, the Purchase on Demand Books at USF generally had a higher rate of use. POD books were checked out $27 \%$ more than all others purchased during the same time period with the same publication dates. Ebooks requested through the POD program had more than $85 \%$ of their pages viewed compared to an average of $45 \%$ for all other ebooks.

The average cost of a POD at USF was $\$ 54.31$ with over half of the material purchased at $\$ 40$ or less. Only $25 \%$ were purchased over $\$ 100$ and fewer still neared the $\$ 200$ limit. These amounts were larger than the average cost of an interlibrary loan not obtained through reciprocal lenders. However, ILL staff noticed at the start of the program some materials requested for purchase had already been interlibrary loaned multiple times by patrons. The assumption made was that POD items were each circumventing multiple ILL requests.

\section{Patron Survey}

Like the Oregon State University Libraries, USF wanted more than the numbers to evaluate its Purchase on Demand program and found the literature lacking in "patron feedback as a measure of program success" (Hussong-Christian, 2010, p. 321). ILL staff had already received various unsolicited messages from patrons about the program, but had no way to 
really pin down patron opinion or awareness. In June 2011 e-mails were sent to 200 ILL users introducing the Purchase on Demand program and asking that they complete a short Internet survey. The sample population had all made interlibrary loan requests more than once a month in the previous calendar year. The ILL manager specifically refrained from polling only those patrons who had received PODs in order to show patron awareness of the program.

Patrons were asked a series of questions to ascertain their knowledge of the program, selection criteria, and whether or not they had ever received a purchased item on their interlibrary loan request. A few questions asked for their opinion of the service and the items purchased, as well as their interlibrary loan requesting habits.

Respondent statuses were equally divided among faculty, teaching/research assistants, and graduates. $46 \%$ of the survey sample responded and only $26 \%$ of respondents were previously aware of the program at all. Only three of those patrons who filled out the survey reported that they kept the survey criteria in mind when making their ILL requests. Patron awareness of the program centered around having received a purchased item on a request they had made. Given that only $10 \%$ of ILL borrowing requests were filled with a POD title, this low number of aware patrons was not a surprise. All patrons who had received a POD title found it useful to have the book for a regular checkout with unlimited option to renew.

The survey also verified that patrons felt the turnaround for delivery of a POD was comparable to a standard interlibrary loan. And while only $81 \%$ of respondents rated the service highly valuable, over $90 \%$ viewed the item purchased on their request to be valuable to the library collection. Only $34.8 \%$ of all surveyed had ever requested a purchase to a collection development librarian. Again like Oregon State University Libraries, USF patrons were generally satisfied and have an overall positive response to the program (Hussong-Christian, 2010).

\section{Conclusion}

The Purchase on Demand program at the University of South Florida was enacted alongside other changes to interlibrary loan. Along with better use and selection of reciprocal 
libraries, and participation in alternative borrowing programs it contributed to a size-able savings in operational costs. Although uncalculated, PODs also provided a savings in postage and mail packaging, as the items did not need to be returned to a lender. Added benefits included the ability to obtain very new material for patrons. ILL had previously faced great adversity obtaining recently published material as other libraries did not always order books as soon as they were published and then typically kept the item unavailable in order to process the items for their own shelves. Many POD items were wholly unavailable through standard ILL channels by virtue of being published in other countries or through self publishing programs.

USF launched their POD program without fan-fair but we were happy to give full explanations when asked, assuring patrons that the turn-around for these purchases was supposed to be as quick or quicker than an ILL. Generally, USF's Purchase on Demand program is a great success and has become so woven into daily processes that it requires no specialized surveillance by managers or project coordinators. It is just one more way interlibrary loan is handled in the library, though it is not held harmless from retooling. The practice of obtaining ebooks whenever possible was begun and continues without patron involvement in the process. The library's acquisition of more and more electronic books has lead some patrons to include format instructions with their request when they do not want a digital delivery. USF POD's next steps might be to include options on the request form that gather this desire more formally like those employed by GIST practitioners (Herrera, 2011).

No matter what model is chosen for a Purchase on Demand program, there are a few rules of thumb that will make it successful. First and foremost, of course, is administrative approval and support. This goes beyond just the department and hierarchy that surrounds the interlibrary loan unit. All involved units need to buy in to the program to keep it functioning. It must be easy for staff to understand and manage. It will be difficult enough to introduce a new process into the daily workload without that process being overly complex. Keep in mind that no POD program will last if it relies on the specialties of one individual. If the program is begun 
around the fact that one ILL staff member happens to have a P-Card, will that ILL position always be issued a P-Card?

A good way to keep your POD program alive is to make it part of other improvements to the work-flow; POD programs can sometimes save money, but more often they just move expenses from one type to another. Improving other practices, like better use of reciprocal agreements can help keep the funds needed for purchasing available so that there is no disruption to the service. And finally, assess assess assess. Not only is it a good practice to regularly compile and examine your ILL statistics, adding budgetary, POD circulation, and patron experience to your assessments will help justify the continued project. 


\section{References}

ALA (2008) Interlibrary Loan Code for the United States Explanatory Supplement. Retrieved July 15, 2011 from:

http://www.ala.org/ala/mgrps/divs/rusa/resources/guidelines/interlibraryloancode.cfm

Alder, Nancy Lichten. (2007) Direct Purchase As a Function of Interlibrary Loan: Buying Books versus Borrowing. Journal of Interlibrary Loan, Document Delivery \& Information Supply. 18(1), 9-15. Retrieved June 20,2011 from: http://www.tandfonline.com/toc/wild20/current.

Herrera, Gail and Greenwood, Judyl (2011) Patron-Initiated Purchasing: Evaluating Criteria and Workflows. Journal of Interlibrary Loan,Document Delivery \& Electronic Reserve. 21(1), 9-24. Retrieved June 20,2011 from: http://www.tandfonline.com/toc/wild20/current Hulsey, Richard. (2003) Purchase on Demand: A Better Customer Service Model. Library Journal. 128(10), 77.

Hussong-Christian, U., \& Goergen-Doll, K. (2010). We're listening: Using patron feedback to assess and enhance purchase on demand. Journal of Interlibrary Loan,Document Delivery \& Electronic Reserve. 20(5), 319-335. Retrieved August 10, 2011 from: http://www.tandfonline.com/toc/wild20/current.

Nixon, Freeman, Ward. (2010) Patron-Driven Acquisitions: An Introduction and Literature Review. Collection Management. 35(3-4), 119-124.

Reighart, Renee, Oberlander, Cyril. (2008) Exploring the future of interlibrary loan: generalizing the experience of the University of Virginia. Interlending \& Document Supply. 36(4), 184-190. Retrieved July 15, 2011 from: http://www.emeraldinsight.com/journals.htm?articleid=1752541.

Ruppel, Margie (2006) Tying Collection development's loose ends with interlibrary loan. Collection building. 25(3), 72-77. Retrieved June 20, 2011 from: http://www.emeraldinsight.com/journals.htm?articleid=1563181 
Tyler, David C. , Melvin, Joyce C. , Xu, Yang, Epp, Marylou and Kreps, Anita M.(2011) Effective Selectors? Interlibrary Loan Patrons as Monograph Purchasers: A Comparative Examination of Price and Circulation-Related Performance. Journal of Interlibrary Loan,Document Delivery \& Electronic Reserve. 21(1), 57-90. Retrieved June 20,2011 from: http://www.tandfonline.com/toc/wild20/current. 